\title{
Induciranje emocija glazbom s osvrtom na ulogu glazbene poduke
}

Tihana Škojo*

tihana.skojo@uaos.hr

https://orcid.org/0000-0003-4709-3139 https://doi.org/10.31192/np.18.1.8

UDK: 78:159.942

001.891.5-053.6

Pregledni članak / Review

Primljeno: 2. listopada 2019.

Prihvaćeno: 3. studenog 2019.

Emocije su kratke i intenzivne reakcije na neki dogadaj, a sastavljene su od kognitivne komponente, subjektivnoga osjećaja, fiziološke reakcije, ekspresije $i$ tendencije djelovanja. Iako je odnos emocija i glazbe moguće promatrati kroz svaku od iskazanih komponenti, primaran aspekt odnosi se na induciranje emocija kod slušatelja gdje slušanje glazbenih ulomaka različite emocionalne obojenosti, potaknuto različitom glazbenom strukturom, kod slušatelja izaziva emocionalni odgovor uključujući i odgovarajuću fiziološku reakciju. Na temelju istraživanja u radu ukazujemo na složen $i$ višeslojni fenomen doživljavanja emocija glazbom. Sukladno iskustvima prijašnjih istraživanja provedeno je novo istraživanje radi ispitivanja odnosa dobi, glazbenoga obrazovanja i poznavanja glazbenoga ulomka te doživljavanja emocija izazvanih glazbenim djelom. U istraživanju su učenici petoga i sedmoga razreda osnovne škole te prvoga i trećega razreda gimnazije bili izloženi slušanju glazbenih primjera te su uz svaki primjer, odabiranjem jedne od šest osnovnih emocija (sreća, tuga, ljutnja, strah, uzbuđenje i smirenost), na ljestvici od 1 (nimalo) do 5 (izuzetno), iskazivali doživljenu emociju. Rezultati ukazuju na važnost glazbenoga znanja i glazbenoga obrazovanja u doživljavanju glazbe te je ovim istraživanjem aktualizirana potreba za širim i interdisciplinarnim promatranjem slušanja glazbe.

Ključne riječi: emocije, glazbeno obrazovanje, slušanje glazbe.

\footnotetext{
* Doc. dr. sc. Tihana Škojo, Sveučilište J. J. Strossmayera u Osijeku, Akademija za umjetnost i kulturu, Kralja Petra Svačića 1F, HR-31000 Osijek.
} 


\section{Uvod}

Emocije su sastavni dio svakoga ljudskoga iskustva, kao relativno kratke, ali intenzivne afektivne reakcije pojedinca na neku pojavnost. Javljaju se u svim područjima ljudskoga djelovanja i nizom povezanih reakcija oblikuju osoban dojam o pojedinom događaju. Sastavljene su od kognitivne komponente, subjektivnoga osjećaja, fiziološke reakcije, ekspresije i tendencije djelovanja. ${ }^{1}$

Sposobnost glazbe da potakne, izmijeni ili oslobodi emocije, da uživa u glazbi, ili se utješi u njoj, fenomen je koji intrigira brojne istraživače tijekom posljednjih stotinu godina ${ }^{2}$ te se uvijek iznova postavlja i pitanje: »Kako zvukovi, koji su, na kraju krajeva, samo zvukovi, imaju moć da tako duboko pokrenu emocije? $\ll^{3}$

U istraživanju o vrstama emocija koje glazba može pobuditi kod slušatelja zaključuje se da glazba može izazvati svih šest osnovnih emocija, ${ }^{4} \mathrm{~s}$ tim da je uočeno teže razlikovanje emocije straha i ljutnje u glazbi, ${ }^{5}$ a najzahtjevnija je za prepoznavanje u glazbi emocija iznenađenja, dok se lakše identificiraju emocija sreće i tuge od straha i ljutnje. ${ }^{6}$

Recentna istraživanja uz vrste emocija ukazuju i na značenje intenziteta emocija, ističući da je važan razlog za slušanje glazbe upravo intenzitet emocija koje glazbeno djelo može izazvati. ${ }^{7}$

Sa subjektivnoga aspekta izdvojeni su čimbenici koji utječu na individualni doživljavaj emocija u glazbi. To su fizički čimbenici (vrijeme i mjesto slušanja), društveni čimbenici (slušanje u samoći ili u društvu) te ostali elementi koji utječu na izvedbu (stupanj uvježbanosti i sl.). Oblikovan je integrirani teorijski okvir BRECVEM (Brain stem reflexes, Evaluative conditioning, Emotional contagion, Visual imagery, Episodic memory and Musical expectancy) ${ }^{8}$ koji se

${ }^{1}$ Usp. Klaus SCHERER, Which Emotions Can br Induced by Music? What Are the Underlying Mechanisms? And How Can We Measure Them?, Journal of New Music Research, 33 (2004) 3, 239-251, 240.

${ }^{2}$ Usp. John A. SLOBODA, Susan A. O'NEILL, Music and emotion. Theory and research, New York, Oxford University Press, 2001, 71-104.

${ }^{3}$ Bennet REIMER, A philosophy of music education. Advancing the vision, New Jersey, Prentice Hall, ${ }^{3} 2003,73$.

${ }^{4}$ Usp. Carol L. KRUMHANSL, An exploratory study of musical emotions and psychophysiology, Canadian Journal of Experimental Psychology, 51 (1997) 4, 336-352, 340.; Christine MOHN, Heike ARGSTATTER, Friedrich-Wilhelm WILKER, Perception of six basic emotions in music, Psychology of Music, 39 (2011) 4, 503-517, 511.

${ }^{5}$ Usp. Elizabeth NAWROT, The perception of emotional expression in music. Evidence from infants, children and adults, Psychology of Music, 31 (2003) 1, 75-92, 88.

${ }^{6}$ Usp. Tina GAŠPAR i dr., Comparison of emotion recognition from facial expression and music, Collegium Antropologium, 35 (2011) 1, 163-167, 166.

7 Usp. Patrik N. JUSLIN, Petri LAUKKA, Expression, perception, and induction of musical emotions. A review and a questionnaire study of everyday listening, Journal of New Music Research, 33 (2004) 3, 217-238, 218.

${ }^{8}$ Usp. Patrik N. JUSLIN, Daniel VÄSTFJÄLL, Emotional responsen to music. The need to consider underlying mechanisms, Behavioral and brain sciences, 31 (2008) 5, 559-621, 563. 
odnosi na čimbenike o kojima ovisi doživljavanje glazbe, ali se naglašava da se ne smije zanemariti složenost glazbene strukture koja također ima značajan utjecaj na intenzitet doživljenih emocija. ${ }^{9}$ Povezanost elemenata glazbenoga izražavanja s emocijama sreće, tuge, ljutnje i straha te izravan utjecaj glazbene strukture na emocije zorno je prikazan u istraživanju u kojem su, variranjem iste melodije, ispitane emocije koje izazivaju pojedini elementi glazbenoga izražavanja..$^{10} \mathrm{U}$ daljnjim je istraživanjima potvrđena povezanosti brzoga i sporoga tempa s osjećajem sreće i tuge, ${ }^{11}$ kao i tonskog roda s pozitivnim i negativnim emocijama. ${ }^{12}$

Najčešća istraživanja o povezanosti emocija i glazbe provedena su s gledišta fizioloških reakcija slušatelja u kojima su dokazane promjene u srčanom ritmu, disanju, krvnom tlaku, temperaturi i elektrodermalnoj reakciji koje se događaju prilikom slušanja pojedinih glazbenih ulomaka s različitim emocionalnim sadržajem. ${ }^{13}$

Radi što je moguće uspješnijega i sveobuhvatnijega pojašnjavanja fenomena povezanosti glazbe i emocija važnu su ulogu imali istraživači koji su proučavali funkcioniranje mozga prilikom slušanja glazbe različite emocionalne obojenosti. ${ }^{14}$

Ispitujući utjecaj dobi i spola na induciranje emocija sreće, tuge, straha i ljutnje u glazbi, zaključuje se da se s godinama poboljšava sposobnost diskriminacije emocija u glazbi, dok su razvidne djelomične razlike između muškaraca i žena. ${ }^{15}$ Posebno je zanimljivo istraživanje o povezanosti glazbene strukture i emocionalnoga sadržaja u kojem su trogodišnja djeca i odrasli slušatelji na temelju 28 glazbenih ulomaka procjenjivali emocije sreće, tuge i ljutnje, a koje

${ }^{9}$ Usp. Blanka BOGUNOVIĆ, Tijana POPOVIĆ MLAĐENOVIĆ, Emotion, Cognition, and Imagery, u: Tijana POPOVIĆ MLAĐENOVIĆ, Blanka BOGUNOVIĆ, Ivana PERKOVIĆ (ur.), Interdisciplinary Approach to Music. Listening, Performing, Composing, Belgrade, Department of Musicology, Faculty of Music, University of Arts, 2014, 191-230, 198.

${ }^{10}$ Usp. Alf GABRIELSSON, Patrik N. JUSLIN, Emotional expression in music performance. Between the performer's intention and the listener's experience, Psychology of Music, 24 (1996) 1, 68-91, 72.; Patrik N. JUSLIN, Cue utilization in communication of emotion in music performance. Relating performance to perception, Journal of Experimental Psychology. Human Perception and Performance, 26 (2000) 6, 1797-1813, 1801.

${ }^{11}$ Usp. Simone Dalla BELLA i dr., A developmental study of the affective value of tempo and mode in music, Cognition, 80 (2001) 3, 1-10, 8.

${ }^{12}$ Usp. Gina M. GERARDI, Louann GERKEN, The Development of Affective Responses to Modality and Melodic Contour, Music Perception, 12 (1995) 3, 279-290, 287.

${ }^{13}$ Usp. Franceska DILLMAN CARPENTIER, Robert F. POTTER, Effects of Music on Physiological Arousal. Explorations into Tempo and Genre, Media Psychology, 10 (2007) 3, 339-363; Patric GOMEZ, Brigitta DANUSER, Relationships between musical structure and psychophysiological measures of emotion, Emotion, 7 (2007) 2, 377-387.

${ }^{14}$ Usp. Anne J. BLOOD, Robert J. ZATORRE, Intensely pleasurable responses to music correlate with activity in brain regions implicated in reward and emotion, Proceedings of the National Academy of Sciences, 98 (2001) 20, 11818-11823.

${ }^{15}$ Usp. Kim G. DOLGIN, Edward H. ADELSON, Age changes in the ability to interpret affect in sung and instrumentally-presented melodies, Psychology of Music, 18 (1990) 1, 87-98, 95. 
je rezultiralo zaključkom da ista glazba pobuđuje iste emocije kod slušatelja različite dobi. ${ }^{16}$ Kvalitativnim se istraživanjima u kojima su ispitanici opisivali odslušano glazbeno djelo zaključuje da se djeca razlikuju od odraslih u opisu odslušanoga glazbenoga djela te da su djeca otvorenija prilikom definiranja glazbe pomoću emocionalnih pojmova. ${ }^{17}$ Dok su djeca opisivala ton, ritam i izvanglazbeni sadržaj, objašnjenja odraslih temeljila su se na tonskoj visini i melodijskom kretanju. Dolazi se do zaključka o većoj otvorenosti djece prilikom definiranja glazbe pomoću emocionalnih pojmova. ${ }^{18}$

Budući da glazba, kao i tekst, ima mogućnost da utječe na emocije brzo i učinkovito, istraživači su u svoja ispitivanja o emocijama u glazbi uključili i odnos teksta i melodije. ${ }^{19}$ Autori ukazuju na to da je glazba dominantnija $u$ izazivanju emocionalnih reakcija od stihova te da stihovi utječu na smanjivanje razine pozitivne emocije, a pojačavaju emocionalne reakcije na tužnu i ljutitu glazbu.

Iz svih navedenih istraživanja razvidno je veliko zanimanje istraživača koji $\mathrm{s}$ različitih gledišta pokušavaju rasvijetliti induciranje emocija kroz glazbu, a dodatni obol tom zanimljivom fenomenu daje i glazbena pedagogija.

\section{Utjecaj glazbenoga obrazovanja na emocije}

Formalna glazbena znanja stječu se u općeobrazovnoj školi i gimnaziji te u glazbenoj školi i na akademijama na kojima se obrazuju profesionalni glazbenici. Ta su znanja rezultat mentalno aktivnoga i analitičkoga pristupa glazbenim djelima koja se sustavno ostvaruju kroz aktivnost slušanja. Za razliku od afektivnoga i senzomotoričkoga slušanja, kakvo je prisutno u svakodnevnom životu gdje je slušatelj prepušten glazbi fiziološki primajući zvukovne podražaje, a u kojem je dominantan jednostavan emocionalni stav slušatelja prema djelu te očitovanje kroz različite promjene $\mathrm{u}$ emocionalnom statusu slušatelja (uzbuđenje - smirenje, napetost - opuštanje i sl.), aktivno analitičko slušanje, kakvo je prisutno u glazbenoj nastavi, umjetnički je pristup sa svojim metodičkim zakonitostima koje rezultiraju izgradnjom glazbenih znanja i glazbenoga uku-

${ }^{16}$ Usp. Elizabeth S. NAWROT, The Perception of Emotional Expression in Music. Evidence from Infants, Children and Adults, Psychology of Music, 31 (2003) 1, 75-92, 77.

${ }^{17}$ Usp. Patricia J. FLOWERS, Attention to elements of music and effect of instruction in vocabulary on written descriptions of music by children and undergraduates, Psychology of Music, 12 (1983) 1, 17-24, 20.

${ }^{18}$ Usp. David J. HARGREAVES, Andrew M. COLMAN, The Dimensions of Aesthetic Reactions to Music, Psychology of Music, 9 (1981) 1, 15-20, 18.

${ }^{19}$ Usp. Valerie N. STRATTON, Annette H. ZALANOWSKI, Affective impact of music vs. Lyrics, Empirical studies of the arts, 12 (1994) 173-184; Shaden Demise SOUSOU, Effects of melody and lyrics on mood and memory, Perceptual and Motor Skills, 85 (1997) 1, 31-40; Omar ALI, Zehra PEYNIRCIOĞLU, Songs and emotions. Are lyrics and melodies equal partners?, Psychology of Music, 34 (2006) 4, 511-534. 
sa. ${ }^{20}$ Takvo je slušanje utemeljeno na analizi i zapažanju izražajnih elemenata (melodije, harmonije, boje, dinamike, ritma, tempa, glazbene forme i oblika). Učenici vođenom aktivnošću te motivirani konkretnim zadatcima aktivno »slušaju i upoznaju umjetnički vrijednu i lijepu glazbu te grade temelj za daljnji razvoj sposobnosti estetskoga procjenjivanja glazbe ${ }^{21}{ }^{21}$

Takvo je estetsko slušanje visok oblik slušanja u kojem se slušatelj ne prepušta pasivno glazbenom podražaju, već glazbeno djelo čini predmetom svojega promatranja i svoje refleksije. ${ }^{22}$ Težište se sa subjektivne reakcije prebacuje na umjetničko djelo. Ono zahtijeva hijerarhijski stupnjevane spoznajne razine koje se kreću od razumijevanja odslušanoga, primjene upoznatoga slušnoga sadržaja, analize i sinteze različitih glazbenih pojavnosti uz stalno prožimanje psihomotoričkoga, kognitivnoga i afektivnoga područja.

Poznavanje glazbe u pedagoškom smislu kreće se od razine prepoznavanja do produktivnoga znanja. Razina prepoznavanja ukazuje na to da pojedinac prepoznaje glazbeno djelo, dijelove skladbe ili skladbu u potpunosti. Reproduktivno znanje imaju pojedinci koji dobro poznaju skladbu i mogu interpretirati njezine dijelove, dok operativno znanje imaju pojedinci, najčešće profesionalni glazbenici, koji dobro poznaju skladbu u cjelini. Produktivno znanje, kao najviši stupanj glazbenoga znanja, odnosi se na potpuno poznavanje glazbenoga djela i notnoga teksta koje je imanentno glazbenicima koji izvode djelo i dirigentima. ${ }^{23}$ Ipak, valja naglasiti da ljudi različitoga glazbenoga obrazovanja različito primaju glazbu s tim da je glazbena obrazovanost važan uvjet slušanja.

Percepcije slušatelja o odslušanoj glazbi i emocionalni okidači u pojedinom djelu mijenjaju se sukladno slušateljevu poznavanju strukturalnih značajki glazbe i glazbe uopće. Provedena istraživanja ukazala su na to da se većim poznavanjem pojedinoga glazbenoga djela povećao intenzitet pozitivnih emocija kod slušatelja, dok se intenzitet negativnih emocija smanjivao. Višekratnim slušanjem i upoznavanjem strukturalnih elemenata slušatelji su otkrivali dijelove u skladbi koji su im postajali sve manje uznemirujući ili neugodni. ${ }^{24}$ Proučavajući učinke ponavljanja glazbenoga djela na fiziološki status ispitanika,

${ }^{20}$ Usp. Pavel ROJKO, Metodika glazbene nastave - praksa II. dio - slušanje glazbe, Zagreb, Jakša Zlatar, 2005, 10, 11, 191, 300.

${ }^{21}$ Usp. Antoaneta RADOČAJ-JERKOVIĆ, Tihana ŠKOJO, Majda MILINOVIĆ, Zborsko pjevanje kao oblik neformalnog učenja i njegov utjecaj na formiranje dječjih glazbenih preferencija, Školski vjesnik - časopis za pedagogiju i praksu, 67 (2018) 2, 311-330, 312.

${ }^{22}$ Usp. Pavel ROJKO, Metodika nastave glazbe. Teorijsko - tematski aspekti, Osijek, Sveučilište Josipa Jurja Strossmayera, 2012, 75, prema: Michael ALT, Didaktik der Musik, Düsseldorf, Pädagogischer Verlag Schwann, 1973.

${ }^{23}$ Usp. Pavel ROJKO, Metodika nastave glazbe. Teorijsko - tematski aspekti, Osijek, Sveučilište Josipa Jurja Strossmayera, 2012, 75, prema: Josip ANDREIS, Vječni Orfej, Zagreb, Školska knjiga, 1967.

${ }^{24}$ Usp. Kari KALLINEN, Niklas RAVAJA, Emotion perceived and emotion felt. Same or different, Musicae Scientiae, 10 (2006) 2, 191-213, 193. 
uočeno je kako su se ponavljanjem slušanja kod slušatelja otkucaji srca značajno smanjivali te da je dolazilo do opuštanja. ${ }^{25}$

Istraživanja emocionalnih odgovora slušatelja s gledišta tonskoga roda najčešće su se temeljila na tonalnoj glazbi, a glazbeni su primjeri sačinjavali odabir skladbi razdoblja klasicizma i romantizma. Rezultati su ukazali na specifične pokretače emocionalnih reakcija na tonsku glazbu. ${ }^{26}$ Istraživanjem elemenata povezanih sa snažnim emocionalnim iskustvom ispitanika na primjeru 10. simfonije G. Mahlera ${ }^{27}$ i Berliozove Sequenze VI. ${ }^{28}$ ukazuje se na konkretne indikatore u glazbenoj strukturi koji vode do pojedinih emocionalnih stanja te se ističe da atonalne harmonijske strukture induciraju emocije napetosti, straha i potencijalne ljutnje. Naglašava se također da je brzi tempo povezan s iznenađenjem i aktivnošću, pojedina harmonijska kretanja povezana su sa strahom, snagom, ljutnjom i gađenjem, dok pauze izazivaju napetost.

Istraživanje emocija na glazbu Clementija, Schoenberga i Beria rezultiralo je zaključkom da ispitanici s glazbenim obrazovanjem pokazuju veće razumijevanje glazbene strukture te da su svjesni i da mogu identificirati emocionalne okidače u predstavljenim tonalnim i atonalnim djelima. Zaključuje se također da atonalna glazba uspješnije prenosi emocionalni intenzitet slušateljima uz glazbeno obrazovanje. ${ }^{29}$

U nekim istraživanjima prilikom razmatranja osjećaja sreće, tuge, ljutnje i straha nisu uočene razlike $u$ induciranim emocijama između glazbenih poznavatelja i osoba koje nisu formalno glazbeno obrazovane te se smatra da univerzalnost glazbenoga jezika podrazumijeva da je i emocionalna poruka koju slušatelj prima istovjetna neovisno o slušatelju. ${ }^{30} \mathrm{~S}$ druge se strane zaključuje da su vrste emocija koje glazba može pobuditi zajedničke kod gotovo svih slušatelja, ali je osjetljivost prema malim razlikama u emocijama koje slušatelj percipira moguća jedino kod glazbenih stručnjaka. ${ }^{31}$

\footnotetext{
${ }^{25}$ Usp. Makoto IWANAGA, Maki IKEDA, Tatsuya IWAKI, The effects of repetitive exposure to music on subjective and physiological responses, Journal of Music Therapy, 33 (1996) 3, 219 230, 228.

${ }^{26}$ Usp. John A. SLOBODA, Music structure and emotional response. Some empirical findings, Psychology of Music, 19 (1991) 2, 110-120, 119.

${ }^{27}$ Usp. Alf GABRIELSSON, Emotions in strong experiences with music, u: Patrik N. JUSLIN, John A. SLOBODA (ur.), Series in affective science. Music and emotion. Theory and research, New York, Oxford University Press, 2001, 431-449.

${ }^{28}$ Usp. Alf GABRIELSSON, Erik LINDSTRÖM, The influence of musical structure on emotional expression, u: Juslin, Sloboda (ur.), Series in affective science..., 223-248.

${ }^{29}$ Usp. Helen DAYNES, Listeners' perceptual and emotional responses to tonal and atonal music, Psychology of Music, 39 (2010) 4, 468-502, 496.

${ }^{30}$ Usp. William W. GAVER, George MANDLER, Play it again, Sam. On Liking Music, Cognition and Emotion, 1 (1987) 3, 259-282, 261.

${ }^{31}$ Usp. John A. SLOBODA, The musical mind, Oxford, Oxford University Press, 1985.
} 


\section{Cilj, problemi i hipoteze istraživanja}

Istraživanje je provedeno radi ispitivanja doživljenih emocija učenika prema klasičnoj europskoj glazbi i umjetničkoj glazbi hrvatskih autora te utjecaja poznatosti glazbenoga primjera na doživljene emocije. U skladu s oblikovanim ciljem postavljeni su sljedeći problemi istraživanja: (1) Ispitati postoji li utjecaj dobi na doživljene emocije; (2) Ispitati postoji li utjecaj spola na doživljene emocije; (3) Ispitati postoji li razlika u doživljavanju emocija između učenika koji su glazbeno obrazovani i onih koji to nisu; (4) Ispitati utjecaj poznavanja glazbenoga djela na doživljene emocije.

Na temelju definiranoga cilja i problema istraživanja postavljene su sljedeće hipoteze: H1: Mlađi učenici u odnosu na starije učenike pokazuju intenzivnije emocije; H2: Učenice u odnosu na učenike pokazuju intenzivnije emocije; H3: Učenici pokazuju intenzivnije emocije prema poznatoj glazbi u odnosu na glazbu koja im nije poznata; H4: Učenici koji su glazbeno obrazovani pokazuju veći intenzitet doživljenih emocija od učenika koji nisu glazbeno obrazovani.

\section{Sudionici}

Ispitivanje je provedeno u Osijeku u Republici Hrvatskoj na uzorku od 314 učenika ( $\check{Z}=197 ; M=117)$ 5. i 7. razreda osnovne škole te 1 . i 3. razreda gimnazije (tablica 1).

Tablica 1. Struktura uzorka $(\mathrm{N}=314)$.

\begin{tabular}{|c|c|c|}
\hline Razred & Broj učenika & Postotak (\%) \\
\hline 5. & 58 & 18,5 \\
\hline 7. & 63 & 20,1 \\
\hline 1. & 97 & 30,9 \\
\hline 3. & 96 & 30,6 \\
\hline Ukupno & 314 & $100 \%$ \\
\hline
\end{tabular}

\section{Instrument i postupak ispitivanja}

Za potrebe istraživanja oblikovan je upitnik koji sadrži dva dijela - u prvom dijelu nalaze se pitanja koja se odnose na obilježja učenika (dob, spol, škola, pohađanje glazbene škole i glazbeno obrazovanje roditelja), a drugi se dio upitnika odnosi na određivanje doživljene emocije, jačinu doživljene emocije i poznavanje glazbenoga djela slušanjem glazbenih primjera. 
U istraživanju je korišten glazbeni nosač zvuka sa šest glazbenih ulomaka (tablica 2) koji je oblikovan isključivo za potrebe ovoga istraživanja. Glazbeni ulomci korišteni u istraživanju odabrani su pomoću nekoliko kriterija. Glazbeni primjeri klasične europske glazbe odabrani su na temelju korištenja u prethodnim istraživanjima o glazbi i emocijama, ${ }^{32}$ dok su primjeri glazbe hrvatskih skladatelja, zbog prvoga takvoga istraživanja u Republici Hrvatskoj, odabrani sukladno istraživačevu percipiranom emocionalnom doživljaju i glazbenom sadržaju. Svaki glazbeni ulomak traje od 1,5 do 2,5 minute i predstavljen je njegov najintenzivniji dio.

Sudionici su odabiranjem jedne od šest osnovnih emocija (sreća, tuga, ljutnja - uznemirenost, strah, uzbuđenje i smirenost), na ljestvici od 1 (nimalo) do 5 (izuzetno) iskazivali doživljenu emociju. Iskazane su emocije prilagođene istraživanjima emocija u glazbi. ${ }^{33}$ Ispitanici su uz doživljenu emociju na ljestvici od jedan (nepoznato) i dva (poznato) procjenjivali je li im glazbeni ulomak poznat od prije ili nije. Sudionicima je objašnjena svrha provođenja istraživanja, zajamčena im je anonimnost te ih se zamolilo da iskreno i precizno odgovaraju na pitanja.

Tablica 2. Primjeri za slušanje.

\begin{tabular}{|l|l|}
\hline & \multicolumn{1}{c|}{ Glazbeni primjer } \\
\hline \multirow{3}{*}{ Umjetnička glazba } & Max Bruch: Kol Nidrei \\
\cline { 2 - 2 } & Johan Strauss: Tritsch-tratsch polka \\
\cline { 2 - 2 } & Georg Friedrich Händel: Halleluia \\
\hline \multirow{2}{*}{$\begin{array}{l}\text { Umjetnička glazba hrvatskih } \\
\text { skladatelja }\end{array}$} & Luka Sorkočević: Simfonija u D-duru br. 3, II. st. Andante \\
\cline { 2 - 2 } & Boris Papandopulo: Studija za klavir br. 6 \\
\cline { 2 - 2 } & Rudolf Matz: Balada za violinu, violončelo i klavir \\
\hline
\end{tabular}

\section{Rezultati istraživanja $i$ interpretacija}

\subsection{Max Bruch: Kol Nidrei}

Slušajući ovaj ulomak, 145 učenika (46,2 \%) navodi da su se osjećali smireno, a 142 učenika (45,2 \%) navodi da su se osjećali tužno, 17 učenika (5,4 \%) učenika osjećalo se uplašeno, 6 učenika $(1,9 \%)$ bilo je ljutito, troje (1\%) uzbuđeno, a samo se jedan učenik $(0,3 \%)$ osjećao sretno pri slušanju ovoga ulomka. Prosje-

\footnotetext{
${ }^{32}$ Usp. Omar ALI, Zehra PEYNIRCIOĞLU, Songs and emotions. Are lyrics and melodies equal partners?, Psychology of Music, 34 (2006) 4, 511-534, 532-534.

${ }^{33}$ Usp. Emery SCHUBERT i dr., The Six Emotion-Face Clock as a Tool for Continuously Rating Discrete Emotional Responses to Music, u: Mitsuko ARAMAKI i dr. (ur.), From sounds to music and emotions, Berlin, Springer Berlin Heidelberg, 2013, 1-19.
} 
čan doživljeni intenzitet emocije koju navode je $\mathrm{M}=3,18$ (SD = 0,932). Za ovaj je ulomak 34 učenika $(10,8 \%)$ navelo da im je poznat.

Da bi se utvrdilo postoje li dobne razlike u doživljenim emocijama, hi-kvadratom je provjereno razlikuju li se opažene od očekivanih učestalosti svake od ponuđenih šest emocija za učenike pojedinih razreda. Hi-kvadrat nije značajan, odnosno učenici različite dobi u podjednakoj mjeri doživljavaju ponuđene emocije. Za dvije emocije koje su sudionici najčešće navodili (smirenost i tuga) provjereno je jednosmjernom analizom varijance postoji li statistički značajna razlika u intenzitetu tih emocija kod učenika različite dobi. Učenici su naveli da je prosječan intenzitet izazvane emocije smirenosti $M=3,16$; $S D=0,940$, što govori da su učenici doživjeli osrednju razinu te afektivne reakcije. Dobne razlike $\mathrm{u}$ intenzitetu nisu značajne $\left(\mathrm{F}_{141,3}=0,429 ; \mathrm{p}=0,733\right)$, odnosno učenici od 5. razreda osnovne do 3 . razreda srednje škole podjednakim intenzitetom, i to osrednjim, reagiraju smirenošću na ovaj primjer. Od onih kojima je ovaj ulomak izazvao emociju tuge, prosječni je intenzitet izazvane tuge za sve sudionike $M=3,20$; $S D=0,949$, a kao i smirenost, i tuga izazvana ovim ulomkom jednako je intenzivna za mlađe i starije sudionike $\left(\mathrm{F}_{138,3}=1,295 ; \mathrm{p}=0,279\right)$. Iz rezultata je razvidno da učenicima ulomak nije poznat, što je očekivano zbog toga jer se navedeni glazbeni primjer ne nalazi na popisu obveznih glazbenih primjera $u$ aktualnom nastavnom planu i programu za osnovnu školu niti u nastavnom programu za gimnazije. ${ }^{34}$

T-testom za nezavisne uzorke provjereno je razlikuju li se učenice od učenika po intenzitetu doživljene emocije te se pokazalo da učenice $(\mathrm{M}=3,31 ; \mathrm{SD}=$ $0,892)$ doživljavaju intenzivnije emocije $\left(\mathrm{t}_{312}=3,29 ; \mathrm{p}=0,001\right)$ od učenika $(\mathrm{M}=$ $2,96$; $\mathrm{SD}=0,959)$. Pokazalo se kako oni kojima je ulomak poznat $(\mathrm{M}=3,88$; $\mathrm{SD}$ $=0,879)$ doživljavaju puno intenzivnije emocije $\left(\mathrm{t}_{312}=-4,83 ; \mathrm{p}=0,000\right)$ od onih kojima je ulomak nepoznat $(\mathrm{M}=3,09 ; \mathrm{SD}=0,903)$.

\subsection{Johan Strauss: Tritsch-tratsch polka}

Tritsch-tratsch polka kod 209 učenika (66,6 \%) izaziva uzbuđenje, a ukupno se 92 učenika (29,3\%) pri slušanju ovoga ulomka osjeća sretno, po petero je učenika (1,6 \%) navelo da se osjeća smireno i ljutito - uznemireno, dva su učenika bila uplašena, a jedan tužan. Prosječan doživljeni intenzitet emocije koju navode je $\mathrm{M}=4,00$ ( $\mathrm{SD}=1,006)$, odnosno prilično je intenzivan. $\mathrm{Za}$ ovaj je ulomak 244 učenika $(77,7 \%)$ navelo da im je poznat.

Hi-kvadratom nisu utvrđene dobne razlike u doživljenim emocijama. Za dvije emocije koje su sudionici najčešće navodili (uzbuđenje i sreća) utvrđeno je

\footnotetext{
${ }^{34}$ Usp. MINISTARSTVO ZNANOSTI, OBRAZOVANJA I ŠPORTA, Nastavni plan i program za osnovnu školu, Zagreb, Ministarstvo znanosti, obrazovanja i športa, 2006; MINISTARSTVO PROSVJETE I KULTURE, Nastavni program Glazbene umjetnosti, Zagreb, Ministarstvo prosvjete i kulture, 1999.
} 
da se učenici različite dobi nisu razlikovali po intenzitetu emocije uzbuđenosti niti po intenzitetu emocije sreće.

Ovaj je ulomak većini učenika poznat, no dodatno se provjerilo hi-kvadratom razlikuje li se čestina onih koji navode da im je ulomak (ne)poznat s obzirom na to koji razred pohađaju. Ovaj je hi-kvadrat značajan $\left(X^{2}=14,79\right.$; $\mathrm{p}=0,002)$. Uvidom $\mathrm{u}$ odnos opaženih i očekivanih frekvencija vidljiv je jasan trend - više učenika (njih 85) trećih razreda srednjih škola navodi da poznaje ulomak, što je očekivano s obzirom na to da je po nastavnom programu upravo u trećem razredu predviđena obrada glazbe 19. stoljeća i skladbi J. Straussa. ${ }^{35}$

Hi-kvadratima je provjereno razlikuju li se čestine emocija koje su naveli kao reakciju na slušano djelo kod učenika različitoga spola, glazbenoga obrazovanja i poznatosti ovoga djela. Pokazalo se da ne postoje spolne razlike, ali postoje statistički značajne razlike $u$ frekvencijama izazvanih emocija ispitanika s obzirom na poznavanje ili nepoznavanje slušanog djela $\left(x^{2}=26,55 ; \mathrm{p}=\right.$ $0,000)$. Učenici koji poznaju djelo $(M=4,15$; $\mathrm{SD}=0,892)$ doživjeli su intenzivnije emocije $\left(t_{312}=-4,60 ; \mathrm{p}=0,000\right)$ od učenika kojima je to djelo nepoznato $(\mathrm{M}=$ $3,54 ; \mathrm{SD}=1,224)$. Pri tome je vidljivo iz prosječnih vrijednosti da oni kojima je djelo poznato doživljavaju dosta intenzivnu emociju, dok je prosječna emocija onih kojima je djelo nepoznato na granici osrednje prema prilično intenzivnim emocijama.

\subsection{Georg Friedrich Händel: Halleluia}

Slušajući ulomak Halleluia, 175 učenika (55,7 \%) navodi da se osjeća sretno, a 109 učenika (34,7 \%) navodi da se osjeća uzbuđeno, 16 učenika (5,1 \%) je bilo smireno, 10 učenika $(3,2 \%)$ je bilo ljutito, a četvero $(1,3 \%)$ uplašeno. Pri tome je intenzitet doživljene emocije prilično visok $(M=4,00 ; S D=0,937)$. Ovaj su ulomak prepoznali gotovo svi učenici (301 učenik ili 95,9\%). Dakle, gotovo svi poznaju ovaj ulomak i preko polovice reagira srećom, a još trećina uzbuđenjem slušajući ga i te su emocije dosta intenzivne.

Prema neznačajnoj vrijednosti hi-kvadrata vidljivo je da učenici različite dobi u jednakim omjerima navode koje su emocije doživjeli, dakle nema dobnih razlika u učestalosti doživljenih emocija.

Nisu se pokazale spolne razlike u doživljenom intenzitetu emocija. Pokazalo se da oni koji su glazbeno obrazovani $(\mathrm{M}=4,43$; $\mathrm{SD}=0,817)$ doživljavaju intenzivnije emocije $\left(t_{312}=-2,67 ; p=0,008\right)$ od učenika koji nemaju glazbeno obrazovanje $(M=3,96 ; S D=0,939)$. Glazbeno obrazovani učenici doživjeli su emocije koje su na granici od prilično prema izuzetno intenzivnim, dok su glazbeno neobrazovani učenici doživjeli prilično intenzivnu emociju.

\footnotetext{
${ }^{35}$ Usp. MINISTARSTVO PROSVJETE I KULTURE, Nastavni program Glazbene umjetnosti, Zagreb, Ministarstvo prosvjete i kulture, 1999, 82.
} 


\subsection{Luka Sorkočević: Simfonija u D-duru br. 3, II. st. Andante}

Ovaj ulomak kod 172 učenika (54,8 \%) izaziva sreću, kod 94 učenika (29,9\%) smirenost, kod 41 učenika $(13,1 \%)$ uzbuđenje, troje učenika (1\%) navodi da je bilo tužno, a po dvoje (0,6 \%) je reklo da je bilo uplašeno i ljutito - uznemireno pri slušanju ovoga djela. Prosječan je doživljeni intenzitet emocije koju navode $\mathrm{M}=3,43$ (SD = 1,068), odnosno od osrednje prema dosta intenzivnoj emociji. Za ovaj je ulomak 112 učenika $(35,7 \%)$ navelo da ga poznaje.

Da bi se provjerilo postoje li dobne razlike u doživljenim emocijama, hi-kvadratom je provjereno razlikuju li se opažene od očekivanih učestalosti svake od ponuđenih šest emocija za učenike pojedinih razreda. Hi-kvadrat je značajan $\left(X^{2}=38,76 ; \mathrm{p}=.001\right)$.

Učenice su $(\mathrm{M}=3,56 ; \mathrm{SD}=1,031)$ doživjele intenzivnije emocije $\left(\mathrm{t}_{312}=2,84\right.$; $\mathrm{p}=0,005)$ od učenika $(\mathrm{M}=3,21 ; \mathrm{SD}=1,097)$. Učenici kojima je ulomak poznat $(\mathrm{M}=3,86 ; \mathrm{SD}=0,879)$ doživljavaju puno intenzivnije emocije $\left(\mathrm{t}_{312}=-5,47 ; \mathrm{p}=\right.$ $0,000)$ od onih kojima je ulomak nepoznat $(\mathrm{M}=3,20$; $\mathrm{SD}=1,042)$ - ovdje je vidljivo da učenici kojima je ulomak poznat navode da im je izazvao prilično intenzivnu emociju, dok je emocija onih kojima je ulomak nepoznat osrednjega intenziteta.

\subsection{Boris Papandopulo: Studija za klavir br. 6}

Ovaj se ulomak ističe po raznolikosti emocija koje je izazvao kod učenika. Njih 84 (26,8 \%) doživjelo je ljutnu - uznemirenost; 73 ili 23,2 \% je bilo uzbuđeno, 62 ili 19,7 \% je bilo uplašeno, 52 ili 16,6 \% je bilo smireno, 33 ili 10,5 \% je bilo sretno, a 10 učenika ili 3,2 \% je doživjelo tugu. Ovakvo raspršenje vjerojatno ukazuje na to da djelo izaziva različite emocionalne reakcije. U prilog tomu ide $\mathrm{i}$ to što je prosječan intenzitet emocionalne reakcije na ovo djelo osrednji ( $\mathrm{M}=$ 2,87; SD = 1,108). Budući da je ulomak prepoznalo 45 učenika ili 14,3\%, smatramo da je prisutno samoiskazano prepoznavanje jer u upitniku nije zatraženo navođenje naziva djela.

Da bi se provjerilo postoje li dobne razlike u doživljenim emocijama, hi-kvadratom je provjereno razlikuju li se opažene od očekivanih učestalosti svake od ponuđenih šest emocija za učenike pojedinih razreda. Hi-kvadrat je značajan $\left(\chi^{2}=36,19 ; \mathrm{p}=0,002\right)$. Budući da je ovo djelo izazvalo u većem broju sve ponuđene emocije, provjereno je za svaku od pet grupa sudionika koji su izabrali pojedinu emocionalnu reakciju (tuga je izostavljena jer ju je doživjelo tek 10 sudionika) postoje li dobne razlike $\mathrm{u}$ intenzitetu emocija. Jednosmjerna analiza varijance provedena na učenicima kojima je ovo djelo izazvalo uzbuđenje pokazala je statistički značajnu razliku $\left(\mathrm{F}_{69,3}=5,184 ; \mathrm{p}=0,003\right)$.

Hi-kvadratom je utvrđeno da se učenice ne razlikuju od učenika, kao ni glazbeno obrazovani od glazbeno neobrazovanih učenika po tome koje su 
emocije naveli kao reakciju na slušano djelo. I za ovaj je ulomak utvrđena razlika između učenika koji su naveli da im je ulomak poznat i onih kojima je nepoznat, uz razinu rizika od $5 \%\left(\chi^{2}=11,68 ; \mathrm{p}=0,039\right)$ - oni kojima je ulomak poznat $u$ većem su broju od očekivanoga naveli da su doživjeli uzbuđenje ili strah, a u manjem broju od očekivanoga smirenost ili ljutitost.

Analize su pokazale da se po intenzitetu doživljenih emocija ne razlikuju učenice od učenika, učenici koji imaju glazbeno obrazovanje od onih koji takvo obrazovanje nemaju te oni kojima je ulomak poznat od onih kojima je ulomak nepoznat.

\subsection{Rudolf Matz: Balada za violinu, violončelo i klavir}

Reakciju tuge ovaj je ulomak izazvao kod 204 ili $65 \%$ učenika, dok je njih 71 ili 22,6 \% bilo smireno kad je slušalo ovaj ulomak, a 18 učenika ili 5,7 \% bilo je uplašeno, 13 ili 4,1 \% ljutito - uznemireno, petero ili 1,6 \% je bilo sretno, a troje ili $1 \%$ je bilo uzbuđeno. Prosječan doživljeni intenzitet emocije koju navode je $\mathrm{M}=3,43(\mathrm{SD}=1,140)$. Za ovaj je ulomak 89 učenika $(28,3 \%)$ navelo da im je poznat.

Usporedbe opaženih i očekivanih frekvencija hi-kvadratima pokazale su da se učenice ne razlikuju od učenika, glazbeno obrazovani od glazbeno neobrazovanih te oni kojima je djelo poznato od onih kojima je nepoznato po tome koje su emocije naveli kao reakciju na slušano djelo. Provjereno je razlikuju li se ove grupe po intenzitetu doživljenih emocija pomoću t-testova. Učenice ( $M$ $=3,58 ; \mathrm{SD}=1,111)$ su doživjele intenzivnije emocije $\left(\mathrm{t}_{312}=3,08 ; \mathrm{p}=0,002\right)$ od učenika $(M=3,18 ; S D=1,149)$, glazbeno obrazovani $(M=3,90 ; S D=1,062) \mathrm{su}$, uz razinu rizika od $5 \%$, doživjeli intenzivnije emocije $\left(t_{312}=-2,38 ; \mathrm{p}=0,018\right)$ nego glazbeno neobrazovani $(\mathrm{M}=3,38$; $\mathrm{SD}=1,139)$ te su oni kojima je djelo poznato $(M=3,88 ; \mathrm{SD}=1,038)$ doživjeli intenzivniju emociju $\left(\mathrm{t}_{312}=-4,58 ; \mathrm{p}=\right.$ $0,000)$ od onih kojima je nepoznato $(\mathrm{M}=3,25$; $\mathrm{SD}=1,131)$.

\section{Zaključak}

Slušanje je glazbe višedimenzionalno iskustvo koje otvara brojna pitanja kod istraživača različitih područja. S gledišta induciranja emocija u glazbi za razumijevanje ovoga fenomena značajan je interdisciplinaran pristup i sinergija psihologije i glazbene pedagogije.

Dobiveni su rezultati potvrdili iskustva iz glazbene prakse i glazbenih istraživanja da učenici prvotno prilaze djelu s emocionalnoga aspekta utvrđivanjem doživljenih emocija. Oni koriste cijeli spektar ponuđenih emocija, sreću, tugu, ljutnju, strah, uzbuđenje i smirenost, da bi iskazali doživljene emocije tijekom 
slušanja pojedinoga glazbenoga djela. Glazbene primjere, po odabranim emocijama, sukladno rezultatima, možemo kategorizirati na one koji su kod učenika dominantno inducirali sreću i uzbuđenje te tugu i smirenost. Strah i ljutnja, iako se pojavljuju kao odabrane emocije, one su inducirane kod malog broja učenika i vezane su uz primjere koji su imali dominantnu emociju tuge.

Od svih predstavljenih glazbenih primjera jedno je djelo kod učenika izazvalo najrazličitije emocionalne reakcije koje se očituju u induciranju svih šest emocija podjednako, a to je šesta studija za klavir B. Papandopula. U ovom je djelu skladatelj, obrađujući cirkusku polku D. Šostakoviča, iskazao iznimnu glazbenu sposobnost prikazivanja ironije, parodije i satire. ${ }^{36}$ Tretirajući klavir kao udaraljku, energično i grubo, ali istovremeno rafinirano, skladatelj je povezao atonalne suzvuke te glazbom iskazao kontradiktorne emocije koje je, sukladno rezultatima istraživanja, uspješno prenio slušateljima.

Iz dobivenih rezultata potvrđeni su rezultati dosadašnjih istraživanja da nema dobnih razlika u doživljavanju emocija. Rezultati istraživanja pokazali su da su učenici koji poznaju pojedini ulomak intenzivnije doživjeli djela od onih koji glazbeno djelo ne poznaju. Iz dobivenih razlika, posebice na primjeru atonalitetne glazbe, razvidna je važnost glazbene poduke za emocionalni doživljaj djela. Ovo saznanje potvrđuje potrebu za egzemplarnim pristupom u obradi glazbenih vrsta i umjetničkim slušanjem koje će, osim glazbenoga znanja, kod slušatelja izvršiti željeni estetski i emocionalan utjecaj.

Saznanja proizašla iz provedenoga istraživanja trebala bi potaknuti učitelje na promišljanje o važnosti emocija u glazbi. Doživljene emocije u glazbi svakako mogu biti dodatni motivatori za slušanje i upoznavanje glazbe u nastavi glazbene kulture i glazbene umjetnosti. One mogu potaknuti učenike na sudjelovanje u izvannastavnim glazbenim aktivnostima i odlaske na koncerte. Svakako emocije daju jedinstvenost u glazbenom doživljaju i bitan su element prilikom oblikovanja budućih ljubitelja umjetničke glazbe.

\footnotetext{
${ }^{36}$ Usp. Dubravko DETONI, Osam studija za klavir, Zagreb, Muzički informativni centar, 2008.
} 


\section{Tihana Škojo* \\ Inducing Emotions through Music and the Role of Musical Education \\ Summary}

Emotions represent short and intense reactions to a particular event, consisting of a cognitive component, subjective feeling, physiological reaction, expression, and tendency of action. Although the relationship between emotions and music can be observed through each of these components, the primary aspect refers to inducing emotions in the listener, whereby listening to musical excerpts of different emotional coloration, motivated by diverse musical structure, causes an emotional response in the listener, including a proper physiological reaction. Based on the research review, the paper highlights a complex and often contradictory phenomenon of recognizing one's own emotions, thereby establishing a clear distinction between the emotions that music expresses and the emotions induced in listeners by specific music. Following the experiences of previous studies, a research has been carried out to examine the relationship between age, music education, familiarity with a musical excerpt, and the experience of emotions induced by a musical piece. In the research, participants were exposed to listening to music examples, and with each example, by selecting one of the six basic emotions (happiness, sadness, anger, fear, excitement, and calmness) on a scale from 1 (not emotional) of 5 (extremely emotional) the emotion they experienced. Along with the experienced emotion, the respondents assessed on a scale from 1 (not familiar) to 2 (well-known) their familiarity with a particular piece of music. The students of the fifth and seventh grade of elementary school, first and third grade of grammar school. The research results point to the importance of familiarity and education in experiencing music, and this research has updated the need for widespread and interdisciplinary study of listening to music.

Key words: education in experiencing music, emotions, listening to music.

(na engl. prev. Tihana Škojo)

\footnotetext{
* Tihana Škojo, PhD, Assis. Prof., Josip Juraj Strossmayer University of Osijek; Academy of Arts and Culture; Address: Kralja Petra Svačića 1F, HR-31000 Osijek, Croatia; E-mail: tihana.skojo@uaos.hr.
} 